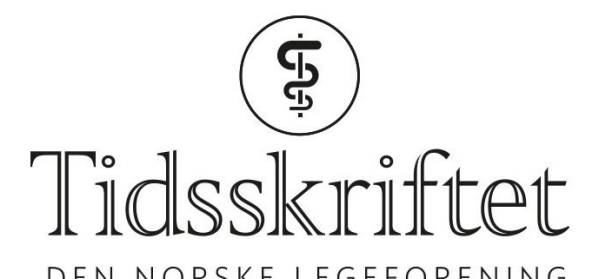

DEN NORSKE LEGEFORENING

\title{
Gratulerer som ferdig lege?
}

I TIDLIGERE TIDER

\section{HANS ERIK HEIER}

E-post: heheier@online.no

Hans Erik Heier er spesialist i immunologi og transfusjonsmedisin, har doktorgrad i cancerimmunologi og mastergrad i helseledelse og helseadministrasjon. Han er professor emeritus og tidligere avdelingsoverlege ved Oslo universitetssykehus.

Forfatteren har fylt ut ICMJE-skjemaet og oppgir ingen interessekonflikter.

Det hvilte høytid over Gamle festsal på Universitetet i Oslo torsdag 12. juni 1969.

Kull 66-1, åtte kvinner og femtifem menn, var blitt candidati medicinae og skulle få sine vitnemål. Både tilstedeværende lærere - alle menn - og kandidatene stilte i galla (bilde).

Ved middagen etterpå holdt candidatus Per Fugelli den eneste eksamensfesttalen som er publisert i Tidsskriftet: Gratulerer som ferdig lege (1). Tittelen fikk mange av oss til å minnes det vår lærer i kvinnesykdommer og fødselshjelp, professor Ernst Schjøtt-Rivers, hadde sagt: «Doktor, når De kommer ut, så husk: DE KAN INGEN TING! INGEN VERDENS TING! Husk det!»

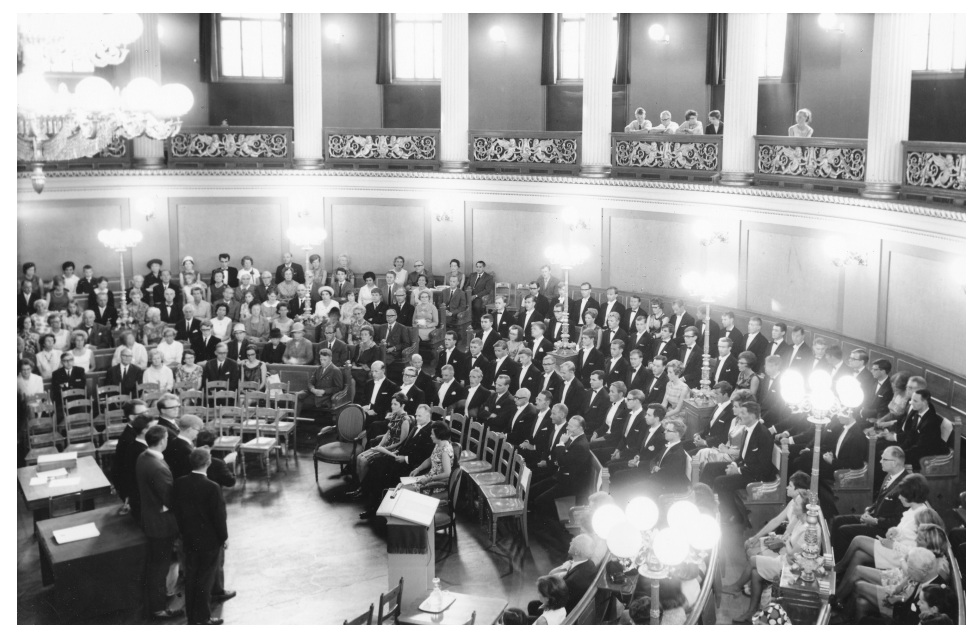

Fugellis hovedpoeng var at vi $i k k e$ var ferdige leger. Vi hadde fått svære mengder teoretisk viten, men lite kunnskap om hverdagsmedisin. Han minnet om de store medisinske fremskrittene som hadde skjedd fram mot 1969 og forutså at de kommende årene ville bli preget av en enda mer eksplosiv utvikling. Han fryktet at det ville føre til en post- og pre- og sub- og superspesialisering som ville splitte opp det medisinske faget. Ved fremtidens jubileer ville alt uselskapelig fagprat forstumme, for ingen ville skjønne hva de andre snakket om.

50 år senere kan vi si: «Det gikk da ikke så verst!» Vi lærte i livets medisinske skole. Som Fugelli forutså, ble kunnskapseksplosjonen voldsommere enn noensinne. De medisinske 
mulighetene anno 2019 kunne man knapt drømme om den gang. Men på ett punkt tok Fugelli feil: Ved våre kulljubileer har vi faglige seminarer og kan fortsatt snakke fag. Vi kan ikke erstatte hverandre, men vi har en felles tenkemåte og forstår mye av det de andre snakker om. Vi lærer fortsatt, også av hverandre. "Det medisinske studium varer livet ut», sa Fugelli. Vi er ikke ferdige leger eller ferdige som leger. Derfor kan vi også se fremover.

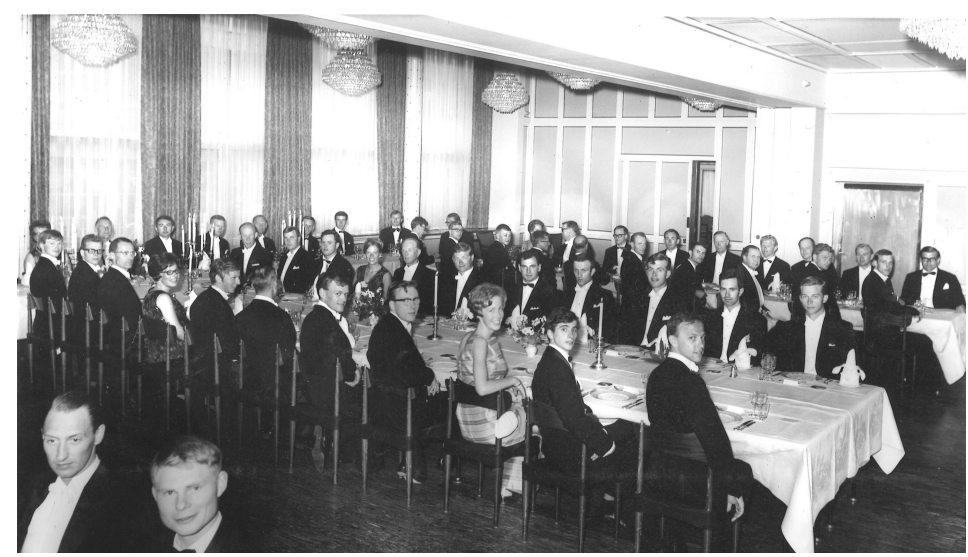

Fugelli påpekte at legens plikt er todelt: 1. Være medmenneske. 2. Være doktor sensu stricto.

Det vil komme nye kunnskapseksplosjoner som skal integreres i et industrialisert og hypereffektivt helsevesen med pakkeforløp. Da kan den største utfordringen for legene bli å være medmenneske (2). Fugellis budskap er at en god lege er en alltid uferdig lege som søker å oppfylle begge deler av legeplikten. Det budskapet bør gjennomsyre all legeutdanning og legepraksis.

\section{LITTERATUR:}

1. Fugelli P. Gratulerer som ferdig lege Tidsskr Nor Legeforen 1969; 89: 1399-40o.

2. Brekke M. Får mennesket plass i pakken? Tidsskr Nor Legeforen 2019; 139. doi: 10.4045/tidsskr.18.o884. [PubMed][CrossRef]

Publisert: 20. juni 2019. Tidsskr Nor Legeforen. DOI:10.4045/tidsskr.19.0103

(C) Tidsskrift for Den norske legeforening 2020. Lastet ned fra tidsskriftet.no 